https://doi.org/10.52058/2695-1592-2021-5(5)-62-74

\title{
Наталія Трушкіна
}

кандидат економічних наук, член-кореспондент Академї економічних наук

України, дійсний член Центру украӥнсько-європейського наукового

співробітництва, стариий науковий співробітник відділу проблем регуляторної політики та розвитку підприємництва, Інститут економіки промисловості НАН України, м. Київ, Україна, e-mail:nata_tru@ukr.net,http://orcid.org/0000-0002-6741-7738

\section{ЦИФРОВИЙ МАРКЕТИНГ В УМОВАХ ГЛОБАЛЬНОГО ІНФОРМАЦЙНОГО ПРОСТОРУ: ТЕОРЕТИЧНІ ПІДХОДИ}

Анотація. Проаналізовано, узагальнено й систематизовано існуючі наукові підходи до суті й змісту поняття «цифровий маркетинг». На цій підставі надано авторський підхід до трактування цифрового маркетингу як ефективного виду діяльності 3 просування продукції із застосуванням сукупності цифрових каналів, інструментів, інформаційно-комунікаційних технологій i систем. Виявлено особливості, відмінності, принципи, головні завдання, переваги цифрового маркетингу. Визначено ключові тенденції розвитку цифрового маркетингу в глобальному інформаційному середовищі.

Ключові слова: цифровий маркетинг, маркетингова діяльність, канали просування, інструменти, клієнтський досвід, цифрові технології, теоретичні підходи, концептуальні засади, трансформація, глобалізація, цифрова економіка, інформаційний простір.

\section{Nataliia Trushkina}

Ph.D. (Economics), Corresponding Member of the Academy of Economic Sciences of Ukraine, Full Member of a Scientific Organisation "The Center for Ukrainian and

European Scientific Cooperation”, Senior Research Fellow of the Department of Regulatory Policy and Entrepreneurship Development, Institute of Industrial Economics of NAS of Ukraine Kyiv, Ukraine, e-mail:nata_tru@ukr.net,http://orcid.org/0000-0002-6741-7738

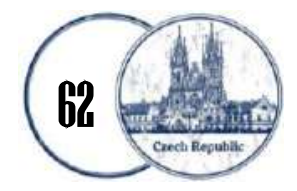




\title{
DIGITAL MARKETING IN THE CONDITIONS OF GLOBAL INFORMATION SPACE: THEORETICAL APPROACHES
}

\begin{abstract}
The existing scientific approaches to the essence and content of the concept of "digital marketing" are analyzed, generalized and systematized. On this basis, the author's approach to the interpretation of digital marketing as an effective activity to promote products using a set of digital channels, tools, information and communication technologies and systems. Features, differences, principles, main tasks, advantages of digital marketing are revealed. The key trends in the development of digital marketing in the global information environment are identified.

Keywords: digital marketing, marketing activity, promotion channels, tools, client experience, digital technologies, theoretical approaches, conceptual bases, transformation, globalization, digital economy, information space.
\end{abstract}

Постановка проблеми. В останнє десятиріччя цифровий маркетинг стає сучасним викликом у результаті зміни парадигми традиційного маркетингу в контексті активізації розвитку глобальної економіки та цифровізації бізнеспроцесів [1-9]. Це, у свою чергу, потребує впровадження принципово нових підходів до формування цифрових каналів просування продукції з урахуванням потреб і попиту споживачів та трансформації маркетингової діяльності на основі інформаційно-комунікаційних технологій і систем.

Це підтверджується і результатами обстеження: 70\% клієнтів бажають використовувати інструменти цифрового маркетингу, але вони абсолютно не розуміють, що це таке.

Як відзначають аналітики Gartner, маркетинг трансформується під впливом таких основних чинників: зміни у поведінці споживачів; більш жорстке законодавство про використання даних; організаційні зміни (у маркетинг привертають все більше фахівців з аналізу даних); автоматизація, яка стає одним 3 ключових елементів маркетингової технології. Під впливом цих чинників до 2022 р. головним стратегічним завданням маркетингової діяльності замість удосконалення споживчого досвіду стане прибутковість. За результатами опитування, проведеного компанією Gartner, встановлено, що 73\% директорів 3 маркетингу мають намір зосередитися на стратегіях 3 невисоким рівнем ризику і низькою прибутковістю, тобто сфокусуватися на існуючих ринках. Приблизно 50\% з них планують збільшувати обсяги продажів уже існуючих товарів, решта 50\% - представити нові товари наявним клієнтам. Тільки 7\% з опитаних директорів з маркетингу мають намір захоплювати у 2021 р. нові ринки, виводячи на них нові продукти. 
За даними Statista, світові витрати на цифрову рекламу щорічно зростають. Так, у 2021 р. їх обсяг збільшиться порівняно з 2019 р. на 35,7\% (з 335,6 до 455,3 млрд дол. США), а у 2024 р. - на 92,4\% або до 645,8 млрд дол.

За розрахунками фахівців eMarketer, витрати на цифрові технології відновлюються, і очікується, що у 2024 р. вони сягнуть 389 млрд дол. США порівняно з 332 млрд дол. у 2020 р. Витрати на рекламу в LinkedIn досягли 1 млрд дол. США, що дозволило мережі стати надійним каналом реклами для В2В-маркетологів. При цьому зазначається, що більшість маркетологів направлять свої зусилля на персоналізацію та поліпшення клієнтського досвіду за допомогою надання рекомендацій послуг і продуктів.

Згідно $з$ доповіддю Forrester «Challenge Traditional Leadership To Win at Digital Transformation», 62\% респондентів, чиї компанії проходять цифрову трансформацію, очолювану директором з маркетингу, підтверджують, що їхній бізнес переживає двозначне зростання порівняно 3 50\% респондентів, де цифровізація управляється ІТ-директорами. У результаті опитування, проведеного у 2018 p. TechProResearch, виявлено, що у 70\% респондентів вже розроблено стратегії цифровізації або вони працюють над цим. А 53\% повідомили, що їхні бюджети щодо цифровізації значно зросли з 2016 по 2017 рр. Слід підкреслити, що цифровізація набула пріоритетного значення не тільки для IT-компаній, а й для підприємств, де маркетинг є однією 3 ключових сфер.

Таким чином, проблеми трансформації маркетингової діяльності із використанням цифрових технологій у контексті активізації розвитку інформаційного середовища залишаються актуальними і вимагають подальших досліджень. I у першу чергу це стосується уточнення категоріальнопонятійного апарату з проблем цифрового маркетингу. Це обумовлено, в першу чергу, тим, що цифрова трансформація у різних видах економічної діяльності породжує необхідність застосування нової термінології, принципів, методів та інструментарію для ведення бізнесу. Тому у науковий обіг введено поняття «цифровий маркетинг», яке вказує на те, що маркетинг функціонує 3 урахуванням певної сукупності чинників, які визначають ефективність системи реалізації товарів (послуг) в епоху цифрових перетворень.

Аналіз останніх досліджень і публікацій. Аналіз й узагальнення наукової літератури свідчить, що зарубіжними й українськими вченими приділяється значна увага:

визначенню 3 різних наукових точок зору суті й змісту понять «електронний бізнес» (D. Chaffey; Д. Свтушенко; Д. Пілевич); «електронна комерція» (V. Zwass; A. Summer, Gr. Dunkan; Д. Козье; О. Юрасов; А. Мартовий; Г. Хубаєв; Р. Царьов; О. Юдін, М. Макарова, Р. Лавренюк;

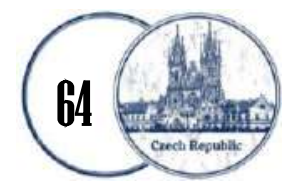


Т. Тардаскіна, Є. Стрельчук, Ю. Терешко; С. Легенчук, А. Скакун; І. Ховрак; Н. Серських; А. Одарченко, К. Сподар; Л. Гармідер, А. Орлова; Г. Маліцька, О. Мельник; Д. Пілевич); «інтернет-торгівля» (Д. Свтушенко); «інтернеткомерція» (А. Одарченко, К. Сподар); «електронна торгівля» (С. Ткаченко, А. Дядін); «електронна роздрібна торгівля» (М. Hargrave);

дослідженню базових інструментів інтернет-маркетингу, які є найбільш ефективними під час просування продукції підприємствами у сучасних умовах розвитку економіки (D. Chaffey, F. Ellis-Chadwick, R. Mayer, K. Johnston; C. Гнатенко, I. Лазнева; Л. Литовченко; Н. Косар, С. Бодьо; I. Падерін, О. Романов, Є. Титовец);

дослідженню переваг і особливостей використання діджитал-інструментів маркетингових комунікацій; визначенню поняття цифрового маркетингу та необхідності вчасного переходу підприємств до даного виду комунікацій зі споживачем в умовах сучасного бізнес-середовища (R. Desai; C. Hofacker; P. Kotler; A. Rohm; K. Wertime; J. R. Saura; D. Ribeiro-Soriano; D. PalaciosMarqués; R. Varadarajan; R. B. Welden; S. Gupta; A. S. Krishen; Y. K. Dwivedi; K. S. Kumar; E. M. Olson; T. M. Key; B. Melović; M. Jocović; B. Dudic; F. L. Théodore; M. López-Santiago; L. Tolentino-Mayo; D. Herhausen; D. Miočević; M. Н. P. Kleijnen; С. Гриценко; Л. Дибчук; М. Матвіїв; М. Окландер; О. Романенко; 3. Андрушкевич; В. Нянько; О. Сітарчук; Л. Мельник; А. Дериколенко; О. Зозульов; С. Ілляшенко; О. Марчук; В. Рубан; Д. Яцюк; І. Рябов; І. Шевкопляс; Ю. Горященко, В. Ільченко);

вдосконаленню управління взаємовідносинами зі споживачами 3 використанням інформаційних технологій (G. Balabanis, K. Keller, P. Kotler, A. Payne, V. Souitaris, С. Крикавський);

практичним аспектам застосування цифрових технологій у маркетинговій діяльності підприємств та обгрунтуванню науково-методичних підходів до оцінювання ефекту від їх впровадження (А. Amaral, L. Barreto, H. Dzwigol, A. Kwilinski, T. Pereira, О. Вишневський, В. Ляшенко).

Разом 3 тим багатогранність, багатоаспектність і дискусійність окремих питань $з$ обраної тематики обумовлюють необхідність подальших наукових розробок. I особливо вирішення даної проблеми актуалізується у сучасних умовах цифрової трансформації бізнес-процесів підприємств, інтенсивного розвитку цифрової економіки та електронної комерції унаслідок COVID-19.

Метою статті $\epsilon$ аналіз, узагальнення й систематизація існуючих теоретичних підходів до визначення змісту терміна «цифровий маркетинг» $\mathrm{i}$ авторське трактування даної економічної категорії.

Теоретико-методологічною основою дослідження $\epsilon$ положення інституціональної теорії, зокрема парадигми еволюційного розвитку, 
концепцій цифрової економіки, маркетингового й логістичного менеджменту, управління

взаємовідносинами зі споживачами.

У процесі дослідження використано такі загальнонаукові методи: аналізу та синтезу - для узагальнення існуючих наукових поглядів i положень, розробок щодо проблем цифрового маркетингу, уточнення понятійнокатегоріального апарату; порівняння та класифікації - для систематизації теоретичних підходів до поняття «цифровий маркетинг»; визначення особливостей і відмінностей цифрового маркетингу та інтернет-маркетингу; експертного опитування - для визначення проблем, специфіки, тенденцій i шляхів трансформації маркетингової діяльності компаній у різних сферах економічної діяльності із застосуванням цифрових технологій.

Виклад основного матеріалу. Розвиток та широке використання інформаційно-комунікаційних технологій і систем в економіці дало підставу для виникнення таких нових категорій, як «електронний бізнес», «інтерактивний бізнес», «інтернет-торгівля», «інтерактивний маркетинг», «електронна торгівля», «електронна комерція». Встановлено, що зарубіжні та вітчизняні дослідники ототожнюють цифровий маркетинг 3 різними термінами (рис. 1).

У науковій літературі можна знайти безліч визначень поняття цифрового маркетингу. Їх аналіз дозволяє зробити висновок, що на сьогоднішній день не існує єдиної наукової позиції стосовно формулювання цієї дефініції. Це обумовлено тим, що науковці є представниками різних наукових шкіл зі своїми підходами й особливостями.

При цьому ряд наукових шкіл ототожнюють це поняття 3 Інтернетмаркетингом. Однак у результаті аналізу наукових джерел і власних досліджень [10-16] виявлено, що цифровий маркетинг включає Інтернет-маркетинг (SEOпросування сайту, контекст, вебінари, тобто всі канали, доступні користувачеві тільки в мережі Інтернет), а також рекламу і просування на будь-яких цифрових носіях поза мережею. Тобто цифровий маркетинг відрізняється від Інтернетмаркетингу за такими ознаками, як цільова аудиторія, сфера впливу на цільову аудиторію, канали поширення, способи комунікації з аудиторією.

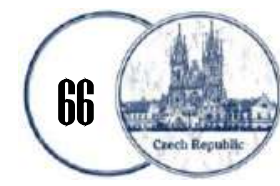


Věda a perspektivy № $5(5) 2021$

ISSN 2695-1584 (Print)

ISSN 2695-1592 (Online)

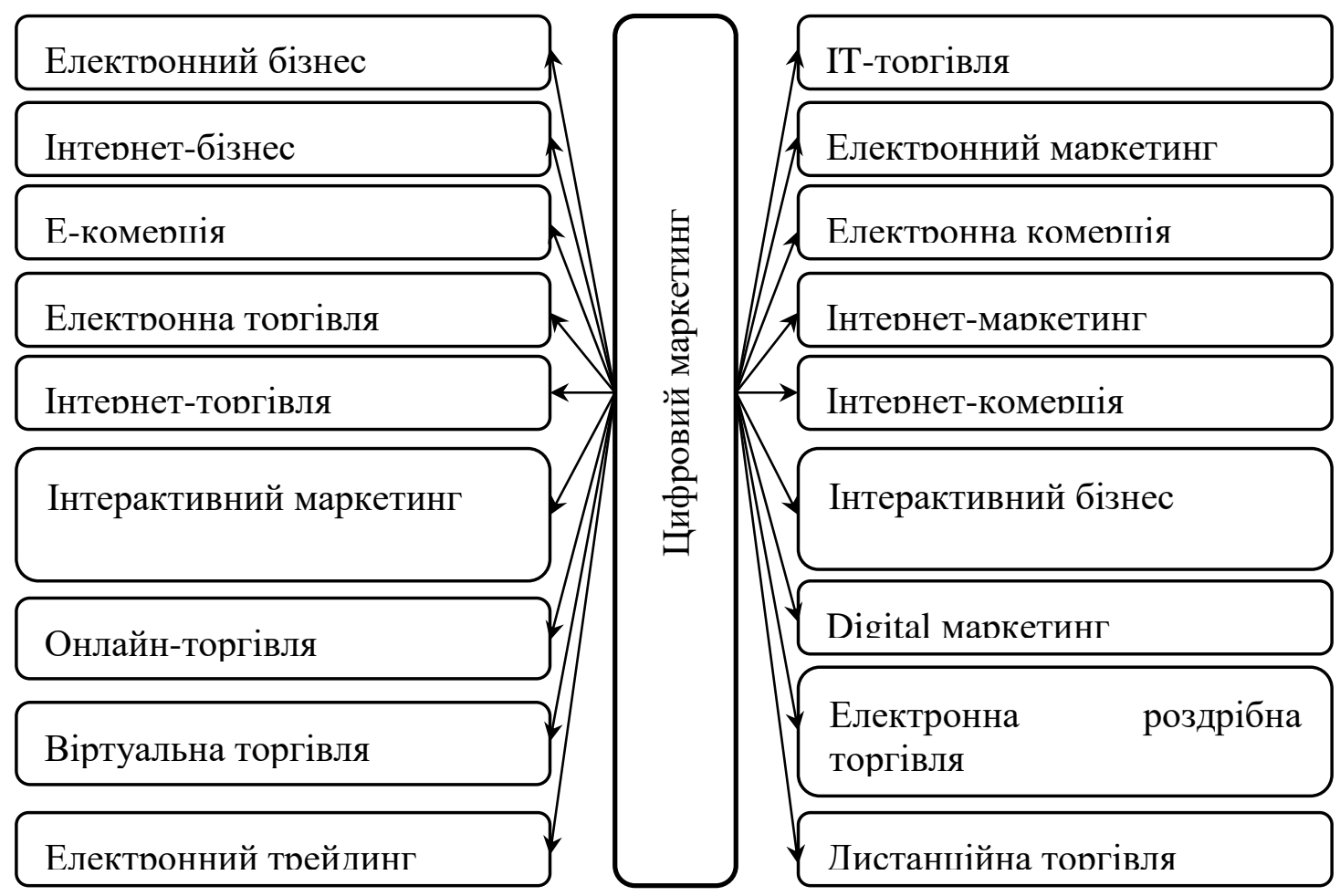

Pис. 1. Понятійно-категоріальний апарат для визначення ичифрового маркетингу (побудовано автором)

Digital (інтерактивний, цифровий) маркетинг розглядається як вид маркетингової діяльності, який передбачає використання різноманітних форм цифрових каналів для взаємодії зі споживачами та іншими контрагентами на ринку (3. Люльчак).

Цифровий маркетинг з точки зору маркетингових комунікацій передбачає використання усіх можливих форм цифрових каналів для просування бренду (Д. Яцюк).

Цифровий маркетинг є однією з важливих сфер сучасного інформаційного суспільства, а також загальним терміном для маркетингу товарів і послуг, який використовує цифрові канали для залучення й утримання клієнтів (О. Марчук).

Цифровий маркетинг - це вид маркетингової діяльності, що дає можливість за цифровими каналами i цифровими методами адресно взаємодіяти з цільовими сегментами ринку у віртуальному i реальному середовищі (М. Окландер, О. Романенко).

Цифровий маркетинг - це весь комплекс маркетингових дій, тобто сучасний маркетинг, якому властива дуальність через його гібридний характер: частина функцій реалізується в онлайн, а частина - в офлайн-середовищі (М. Окландер, О. Романенко).

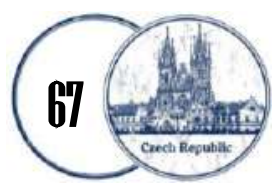


Цифровий маркетинг - це використання всіх можливих форм цифрових каналів для просування фірми та іiі товару (О. Карпіщенко, Ю. Логінова).

В узагальненому вигляді цифровий маркетинг включає три складники: контент, дизайн і статистику. Цифровий маркетинг являє собою комплексний підхід до просування компанії, іiі продуктів у цифровому середовищі, а також охоплює офлайн-споживачів (О. Бєлікова, I. Фоміченко, В. Шашко, Ю. Ніколаєва).

Цифровий маркетинг - це маркетинг, який шляхом використання цифрових інформаційно-комунікаційних технологій здійснює адресне розповсюдження маркетингових комунікацій цільовій аудиторії та реалізація маркетингової діяльності у віртуальному i реальному середовищах (Л. Романенко).

Таким чином, у результаті проведеного теоретичного аналізу узагальнено різні наукові підходи до визначення суті та змісту поняття «цифровий маркетинг» (рис. 2). Вчені та фахівці під цією дефініцією, як правило, розуміють:

інструмент комунікацій;

вид маркетингової діяльності, яка здійснюється за допомогою цифрових каналів просування продукції;

цифрову комунікацію, яка відбувається і онлайн, і офлайн;

комплексне просування, яке включає в себе безліч каналів;

використання всіх можливих форм цифрових каналів для просування бренду;

спосіб просування бізнесу за допомогою цифрових технологій;

комплексний підхід до просування продукції в цифровому середовищі;

просування бренду і залучення клієнтів за допомогою всіх можливих цифрових каналів (соціальні мережі, Інтернет, е-таil-розсилка, контекстна реклама, контент-маркетинг);

комплексне просування продукту або послуги за допомогою різних видів маркетингу;

інтеграцію великої кількості різних технологій (соціальних, мобільних, веб, CRM-системи) з продажами і клієнтським сервісом;

комплекс різних маркетингових інструментів для залучення клієнтів як 3 онлайн, так і офлайн-середовища;

мультиканальне просування бізнесу в інформаційному просторі;

маркетинг, який забезпечує взаємодію з клієнтами і бізнес-партнерами за допомогою цифрових інформаційно-комунікаційних технологій та електронних пристроїв; 
Věda a perspektivy № 5(5) 2021

ISSN 2695-1584 (Print)

ISST 2695-1592 (Online)

реалізацію маркетингової діяльності із застосуванням цифрових інформаційно-комунікаційних технологій.

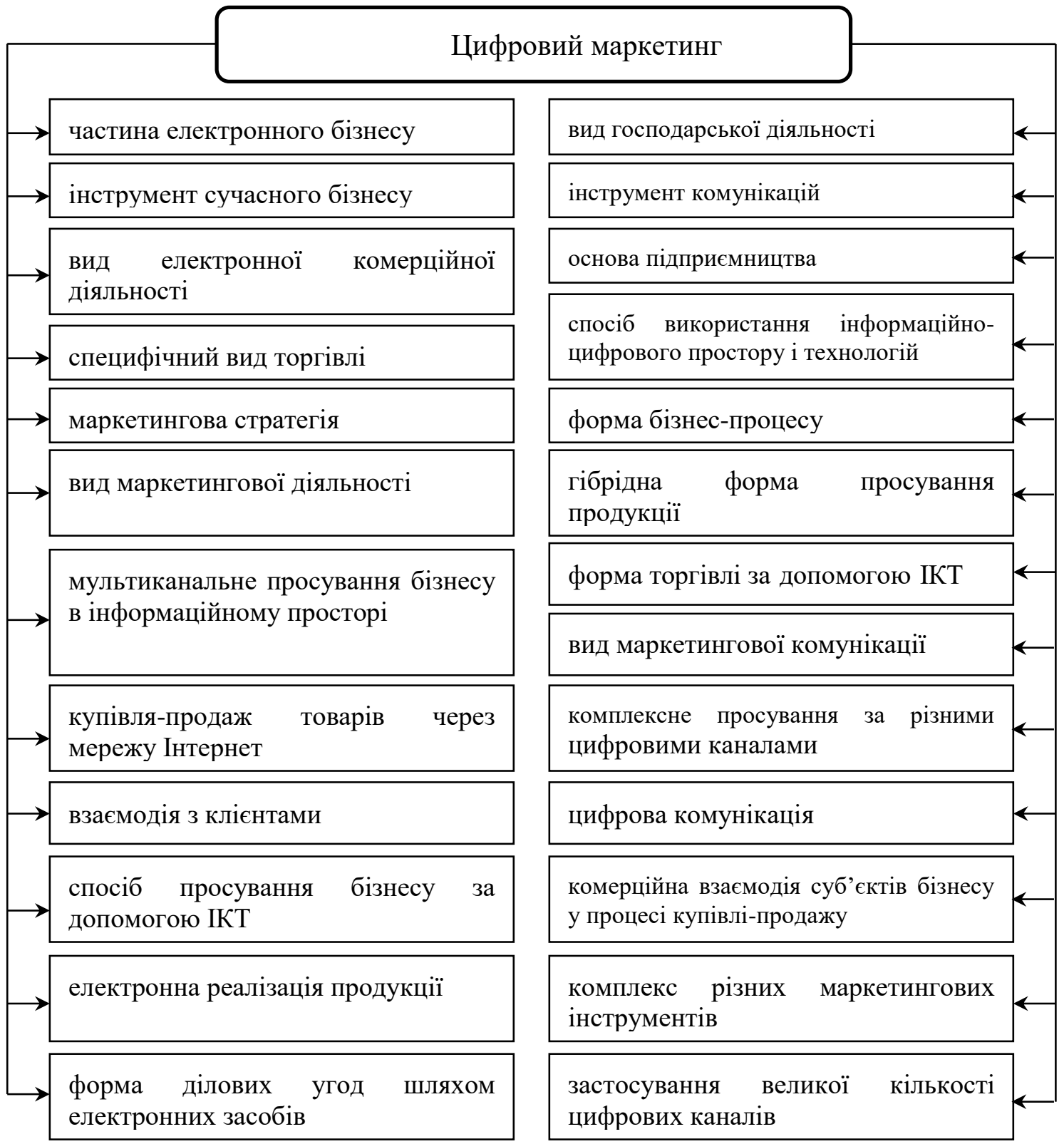

Puc. 2. Систематизація наукових підходів до формулювання терміна «иифровий маркетинг» (запропоновано автором)

Узагальнення теоретичних положень щодо даної проблематики дозволило запропонувати підхід до визначення суті та змісту поняття «цифровий маркетинг» 3 таких позицій:

складова електронного бізнесу;

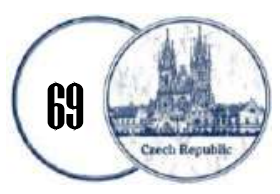


ефективний вид діяльності 3 просування продукції із застосуванням сукупності цифрових каналів та інструментів;

комплексний маркетинговий підхід до просування продукції в глобальному цифровому просторі;

система партнерських взаємовідносин зі споживачами із використанням різних цифрових каналів у контексті реалізації концепції маркетингу відносин;

вид маркетингової діяльності, організація якої здійснюється за допомогою цифрових технологій та інформаційних систем;

інструмент маркетингової діяльності в умовах цифрової трансформації бізнес-процесів.

Відмінними рисами цифрового маркетингу $\epsilon$ : інтерактивність; таргетованість; можливість проведення веб-аналітики.

До основних принципів цифрового маркетингу можна віднести: присутність в інформаційному цифровому просторі, брендинг і партнерські взаємовідносини.

Головна мета digital-маркетингу полягає у залученні й утриманні клієнтів, збільшенні прибутковості бізнесу. Досягнення мети відбувається виключно завдяки залученню відвідувачів Інтернет-ресурсу та їх трансформації у потенційних, а потім у лояльних покупців.

До завдань цифрового маркетингу можна віднести збір контактних даних зацікавлених користувачів; підвищення охоплення бренду; формування позитивного іміджу; підвищення споживчої лояльності; збір даних для маркетингових досліджень; інформування цільової аудиторії; формування бази постійних клієнтів. Він виконує повний спектр маркетингових завдань, але використовує Інтернет як основний канал взаємодії з аудиторією.

Каналами цифрового маркетингу є: контент-маркетинг (SEO, SERM, SMM, контент PR, E-mail маркетинг, ORM); digital-реклама (контекстна, таргетована, медійна реклама); мультиканальне просування; веб-аналітика.

Серед переваг digital-маркетингу можна назвати інтерактивність, швидкість, універсальність, відсутність територіальних обмежень, легкий доступ до ресурсів, залучення цільової аудиторії тощо.

Висновки. Виходячи з вищевикладеного можна дійти такого висновку. Інтенсивний розвиток цифрової економіки, збільшення обсягів електронної комерції, персоналізація послуг, прискорення темпів інтегрованості нових користувачів до мережі Інтернет, поява сучасних викликів і вимог споживачів вимагають пошуку сучасних шляхів і механізмів діджиталізації маркетингової діяльності.

Встановлено, що до ключових тенденції розвитку цифрового маркетингу віднесено таке: 
1) від цифрової маркетингової діяльності до практичних заходів - коли вибухнула пандемія, споживачі зосередилися на використанні нових технологій і роботі у режимі онлайн. Але у 2021 р. багато споживачів не мають намір проводити більшу частину часу у мережі Інтернет. Підтримка активності клієнтів буде залежати від того, наскільки якісний клієнтський досвід вони будуть надавати. Тому маркетологи мають оцінити свій цифровий потенціал i вдосконалити його, щоб залучити клієнтів, не викликаючи «цифрової втоми»;

2) клієнтський досвід поєднується 3 іншими функціями. За прогнозними розрахунками Gatne, до 2023 p. 25\% компаній планують об'єднати маркетинг 3 продажами і обслуговуванням клієнтів у єдину функцію. Мета полягає в тому, щоб функції, які орієнтовано на клієнта, працювали спільно, доповнюючи одна одну;

3) заняття і модерація контенту стануть більш важливими. За експертними оцінками Gamter, до 2024 p. 33\% компаній буде вважати модерацію користувацького контенту пріоритетним завданням. Використання програмного продукту та інструментів дозволять компаніям контролювати, модерувати призначений для користувача контент i керувати ним для запобігання негативного впливу на їх бренди.

Дослідження Admixer та IAB Ukraine показують, що пандемія COVID-19 змусила 70\% українських підприємств скорочувати операційні бюджети, а $30 \%$ бізнесу довелося урізати й рекламні. Щоб впоратися 3 наслідками кризи, брендам необхідно розробити стратегічний план дій.

При цьому компанії акуратно підходять до стратегічного планування на 2022 р.: 72\% опитаних брендів зосередяться на поточних ринках, і тільки 18\% мають намір виходити на нові. Більшість компаній не готові до різких маневрів: 56,4\% респондентів не планують багато витрачати на експерименти, 39\% згодні на обмежений ризик і тільки 5\% відкриті для експериментів і не бояться ризиків.

59\% бренд-маркетологів вважають найбільш пріоритетним 3 точки зору маркетингу створення креативів і контенту, 54\% опитаних роблять акцент на лідогенераціi, а $51 \%$ розділилися між персоналізацією/тестуванням гіпотез і мультиканальним маркетингом.

$63 \%$ агентств впевнені, що найважливішим для маркетологів буде стратегічне планування. 57\% думають, що це креатив і контент, а 49\% віддали голос за персоналізацію i тестування гіпотез. А дизайну i розробкам приділяється незначна увага.

Отже, компанії планують більше інвестувати у взаємовідносини 3 клієнтами, лояльність й утримання. Їм необхідна стабільна база користувачів і передбачуваний потік доходів. Персоналізація спілкування з користувачами й інтегровані додатки будуть першочерговими завданнями для компаній, які хочуть поліпшити клієнтський досвід. Все це свідчить про актуальність

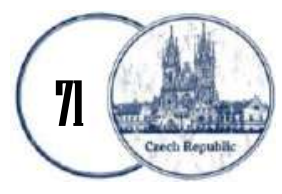


наукових досліджень з проблем цифрового маркетингу.

Перспективи подальших наукових досліджень полягають у визначенні змісту термінів «маркетингова діяльність підприємства в умовах цифрової економіки», «стратегічне управління маркетинговою діяльністю підприємства в умовах цифровізації», «трансформація маркетингової діяльності підприємств в умовах цифрової економіки»; в обгрунтуванні й розробленні стратегії маркетингової діяльності підприємств у контексті цифрових трансформацій.

\section{Лimepamypa:}

1. Koev S. R., Tryfonova O., Inzhyievska L., Trushkina N., Radieva M. Management of Domestic Marketing of Service Enterprises. IBIMA Business Review. 2019. Vol. 2019. P. 1-13. https://doi.org/10.5171/2019.681709.

2. Sandiuk H., Lushpiienko Yu., Trushkina N., Tkachenko I., Kurganskaya E. Special Procedures for Electronic Public Procurement. Journal of Legal, Ethical and Regulatory Issues. 2019. Vol. 22. Special Issue 2. Business laws and legal rights: research and practice. P. 1-6. URL: https://www.abacademies.org/articles/special-procedures-for-electronic-public-procurement-15440044-22-SI-2-351.pdf.

3. Kashchena N., Solokha D., Trushkina N., Potemkin L., Mirkurbanova R. Use of multiagent simulation modeling for predicting the sales of wholesale trade companies. Journal of Management Information and Decision Sciences. 2019. Vol. 22(4). P. 483-488.

4. Trushkina N. Transformation of customer relationship management in the digital economy. Digital economy and digital society: monograph / Edited by T. Nestorenko, M. WierzbikStronska; Katowice School of Technology. Katowice: Wydawnictwo Wyzszej Szkoly Technicznej w Katowicach, 2019. P. 311-316.

5. Zaloznova Yu., Trushkina N. Management of logistic activities as a mechanism for providing sustainable development of enterprises in the digital economy. Virtual Economics. 2019. Vol. 2. No 1. P. 63-80. https://doi.org/10.34021/ ve.2019.02.01(4).

6. Trushkina N. Development of the information economy under the conditions of global economic transformations: features, factors and prospects. Virtual Economics. 2019. Vol. 2. No. 4. P. 7-25. https://doi.org/10.34021/ve.2019.02.04(1).

7. Hryhorak M., Trushkina N., Popkowski T., Molchanova K. Digital transformations of logistics customer service business models. Intellectualization of Logistics and Supply Chain Management. 2020. Vol. 1. P. 57-75. https://doi.org/10.46783/smart-scm/2020-1-6.

8. Трушкіна Н.В. Клієнтоорієнтований підхід до логістичного сервісу в умовах інформаційної економіки. Бізнес Інформ. 2020. № 6. С. 196-204. https://doi.org/10.32983/22224459-2020-6-196-204.

9. Trushkina N., Dzwigol H., Serhieieva O., Shkrygun Yu. Development of the Logistics 4.0 Concept in the Digital Economy. Economic Herald of the Donbas. 2020. № 4 (62). P. 85-96. https://doi.org/10.12958/1817-3772-2020-4(62)-85-96.

10. Kwilinski A., Trushkina N. Features of digital marketing in the context of informational economy. Modern innovative and information technologies in the development of society: monograph / Edited by M. Ekkert, O. Nestorenko, M. Szynk; Katowice School of Technology. Katowice: Wydawnictwo Wyzszej Szkoly Technicznej w Katowicach, 2019. P. 158-165.

11. Місюкевич В. І., Трушкіна Н. В., Шкригун Ю. О. Електронна комерція у глобальному цифровому просторі: нові виклики та напрями. Формування системи

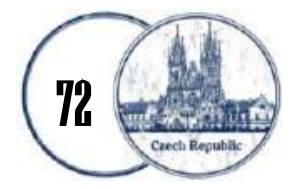


внутрішньої торгівлі України: теорія, практика, інноващії: колективна монографія / за ред. В. В. Лісіци, В. І. Місюкевич, О. М. Михайленко. Полтава: ПУЕТ, 2020. С. 150-162.

12. Trushkina N., Bezpartochnyi M., Shkrygun Yu. E-commerce in the conditions of digitalization of business processes. Strategies, models and technologies of economic systems management in the context of international economic integration: scientific monograph / edited by M. Bezpartochnyi, V. Riashchenko, N. Linde. 2nd ed. Riga: Institute of Economics of the Latvian Academy of Sciences, 2020. P. 245-256.

13. Trushkina N., Bezpartochna O., Shkrygun Yu. Priority directions for development of digital marketing in the conditions of globalization. Pandemic Economic Crisis: Changes and New Challenges to Society: scientific monograph / edited by M. Bezpartochnyi; VUZF University of Finance, Business and Entrepreneurship. Sofia: VUZF Publishing House "St. Grigorii Bogoslov", 2020. P. 227-238.

14. Трушкіна Н. В., Сергєєва О. Р., Шкригун Ю. О. Концептуальні підходи до визначення поняття «електронна комерція». Проблеми економіки. 2020. № 4. С. 231-240. https://doi.org/10.32983/2222-0712-2020-4-231-240.

15. Bezpartochna O., Misyuckevich V., Trushkina N. E-commerce trends in the digital economy. Artificial intelligence as a basis for the development of the digital economy: textbook / Edited by I. Tatomyr, Z. Kvasnii; The Precarpathian Institute named of M. Hrushevsky of Interregional Academy of Personnel Management. Praha: OKTAN Print s.r.o., 2021. P. 367-376.

16. Bezpartochna O., Trushkina N. E-commerce in the age of digital transformation. Concepts, strategies and mechanisms of economic systems management in the context of modern world challenges: scientific monograph / VUZF University of Finance, Business and Entrepreneurship. Sofia: VUZF Publishing House "St. Grigorii Bogoslov", 2021. P. 306-318.

\section{References:}

1. Koev, S. R., Tryfonova, O., Inzhyievska, L., Trushkina, N., Radieva, M. (2019). Management of Domestic Marketing of Service Enterprises. IBIMA Business Review, 2019, 1-13. https://doi.org/10.5171/2019.681709.

2. Sandiuk, H., Lushpiienko, Yu., Trushkina, N., Tkachenko, I., Kurganskaya, E. (2019). Special Procedures for Electronic Public Procurement. Journal of Legal, Ethical and Regulatory Issues, 22, 1-6, https://www.abacademies.org/articles/special-procedures-for-electronic-public-procurement1544-0044-22-SI-2-351.pdf.

3. Kashchena, N., Solokha, D., Trushkina, N., Potemkin, L., Mirkurbanova, R. (2019). Use of multi-agent simulation modeling for predicting the sales of wholesale trade companies. Journal of Management Information and Decision Sciences, 22(4), 483-488.

4. Trushkina, N. (2019). Transformation of customer relationship management in the digital economy. In T. Nestorenko, M. Wierzbik-Stronska (Eds.), Digital economy and digital society: monograph (pp. 311-316). Katowice: Wydawnictwo Wyzszej Szkoly Technicznej w Katowicach.

5. Zaloznova, Yu., Trushkina, N. (2019). Management of logistic activities as a mechanism for providing sustainable development of enterprises in the digital economy. Virtual Economics, 2(1), 6380. https://doi.org/10.34021/ ve.2019.02.01(4).

6. Trushkina, N. (2019). Development of the information economy under the conditions of global economic transformations: features, factors and prospects. Virtual Economics, 2(4), 7-25. https://doi.org/10.34021/ve.2019.02.04(1).

7. Hryhorak, M., Trushkina, N., Popkowski, T., Molchanova, K. (2020). Digital transformations of logistics customer service business models. Intellectualization of Logistics and Supply Chain Management, 1, 57-75. https://doi.org/10.46783/smart-scm/2020-1-6.

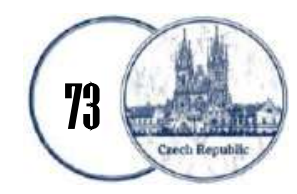




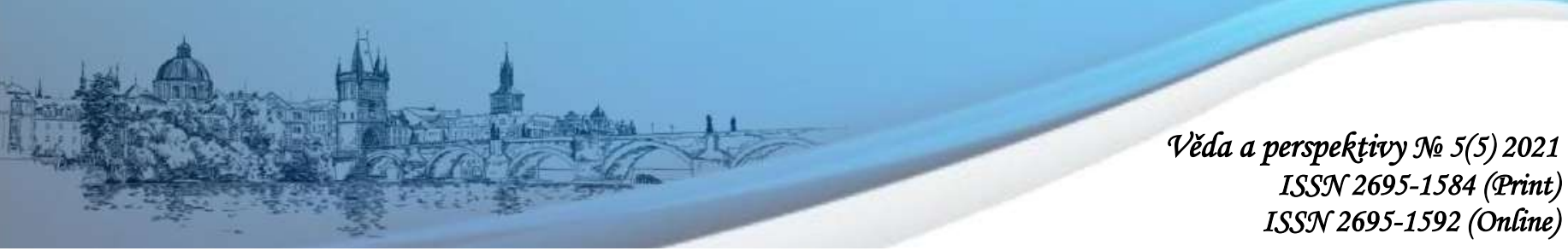

8. Trushkina, N. V. (2020). Kliientooriientovanyi pidkhid do lohistychnoho servisu v umovakh informatsiinoi ekonomiky [Customer-oriented approach to logistics service in the information economy]. Biznes Inform - Business Inform, 6, 196-204. https://doi.org/10.32983/2222-4459-2020-6196-204 [in Ukrainian].

9. Trushkina, N., Dzwigol, H., Serhieieva, O., Shkrygun, Yu. (2020). Development of the Logistics 4.0 Concept in the Digital Economy. Economic Herald of the Donbas, 4(62), 85-96. https://doi.org/10.12958/1817-3772-2020-4(62)-85-96.

10. Kwilinski, A., Trushkina, N. (2019). Features of digital marketing in the context of informational economy. In M. Ekkert, O. Nestorenko, M. Szynk (Eds.), Modern innovative and information technologies in the development of society: monograph (pp. 158-165). Katowice: Wydawnictwo Wyzszej Szkoly Technicznej w Katowicach.

11. Misyukevich, V.I., Trushkina, N.V., Shkrygun, Y.O. (2020). Elektronna komertsiia u hlobalnomu tsyfrovomu prostori: novi vyklyky ta napriamy [Electronic commerce in the global digital space: new challenges and directions]. In V. Lisitsy, V. Misyukevich, O. Mikhailenko (Eds.), The formation of the system of internal trade of Ukraine: theory, practice, innovation: a collective monograph (pp. 150-162). Poltava: PUET [in Ukrainian].

12. Trushkina, N., Bezpartochnyi, M., Shkrygun, Yu. (2020). E-commerce in the conditions of digitalization of business processes. In M. Bezpartochnyi, V. Riashchenko, N. Linde (Eds.), Strategies, models and technologies of economic systems management in the context of international economic integration: scientific monograph (pp. 245-256). 2nd ed. Riga: Institute of Economics of the Latvian Academy of Sciences.

13. Trushkina, N., Bezpartochna, O., Shkrygun, Yu. (2020). Priority directions for development of digital marketing in the conditions of globalization. In M. Bezpartochnyi (Ed.), Pandemic Economic Crisis: Changes and New Challenges to Society: scientific monograph (pp. 227-238). Sofia: VUZF Publishing House "St. Grigorii Bogoslov".

14. Trushkina, N.V., Serhieieva, O.R., Shkryhun, Yu.O. (2020). Kontseptualni pidkhody do vyznachennia poniattia «elektronna komertsiia» [Conceptual approaches to the definition of "ecommerce"]. Problemy ekonomiky - Problems of the economy, 4, 231-240. https://doi.org/10.32983/2222-0712-2020-4-231-240 [in Ukrainian].

15. Bezpartochna, O., Misyuckevich, V., Trushkina, N. (2021). E-commerce trends in the digital economy. In I. Tatomyr, Z. Kvasnii (Eds.), Artificial intelligence as a basis for the development of the digital economy: textbook (pp. 367-376). Praha: OKTAN Print s.r.o

16. Bezpartochna, O., Trushkina, N. (2021). E-commerce in the age of digital transformation. Concepts, strategies and mechanisms of economic systems management in the context of modern world challenges: scientific monograph (pp. 306-318). Sofia: VUZF Publishing House "St. Grigorii Bogoslov". 